\title{
Anti-angiogenic activity of cranberry proanthocyanidins and cytotoxic properties in ovarian cancer cells
}

\author{
KYU KWANG KIM ${ }^{1}$, AJAY P. SINGH ${ }^{2,3}$, RAKESH K. SINGH ${ }^{1}$, ANGELICA DeMARTINO ${ }^{1}$, \\ LAURENT BRARD ${ }^{4}$, NICHOLI VORSA ${ }^{2,3}$, THILO S. LANGE ${ }^{1,5}$ and RICHARD G. MOORE ${ }^{1}$
}

\begin{abstract}
${ }^{1}$ Molecular Therapeutics Laboratory, Program in Women's Oncology, Department of Obstetrics and Gynecology, Women and Infants' Hospital, Alpert Medical School, Brown University, Providence, RI 02905; ${ }^{2}$ Department of Plant Biology, Rutgers University, New Brunswick, NJ 08901; ${ }^{3}$ Philip E. Marucci Center for Blueberry and Cranberry Research and Extension, Rutgers University, Chatsworth, NJ 08019; ${ }^{4}$ Division of Gynecologic Oncology, Department of Obstetrics and Gynecology, Southern Illinois University School of Medicine, IL 62794; ${ }^{5}$ Department of Molecular Biology, Cell Biology and Biochemistry, Brown University, Providence, RI 02912, USA
\end{abstract}

Received April 27, 2011; Accepted May 30, 2011

DOI: $10.3892 /$ ijo.2011.1198

\begin{abstract}
Cranberry extracts may provide beneficial health effects in the treatment of various diseases, including cancer. However, the underlying molecular mechanisms of antineoplastic properties are not understood. We report the effect of a proanthocyanidin (PAC)-rich isolate from cranberry (PAC-1) as a therapeutic agent with dual activity to target both ovarian cancer viability and angiogenesis in vitro. PAC-1 treatment of chemotherapy-resistant SKOV-3 cells blocked cell cycle progression through the $\mathrm{G}_{2} / \mathrm{M}$ phase, increased the generation of reactive oxygen species (ROS), and induced apoptosis through activation of intrinsic and extrinsic pathway components. Cytotoxicity of PAC-1 was partially based on ROS generation and could be blocked by co-treatment with antioxidant glutathione. PAC-1 reduced the cell viability of both SKOV-3 ovarian cancer cells and HUVEC endothelial cells in a dose-dependent manner and blocked the activation of the pro-survival factor AKT. Furthermore, PAC-1 blocked vascular endothelial growth factor (VEGF)-stimulated receptor phosphorylation in endothelial cells, which correlated with the inhibition of endothelial tube formation in vitro. Our findings suggest that PAC-1 exerts potent anticancer and anti-angiogenic properties and that highly purified PAC from cranberry can be further developed to treat ovarian cancer in combinational or single-agent therapy.
\end{abstract}

Correspondence to: Dr Kyu Kwang Kim, Molecular Therapeutics Laboratory, Program in Women's Oncology, Department of Obstetrics and Gynecology, Women and Infants Hospital of Rhode Island, 101 Dudley Street, Providence, RI 02905, USA

E-mail:kkim@wihri.org

Key words: cranberry, proanthocyanidin, ovarian cancer, angiogenesis, reactive oxygen species

\section{Introduction}

Ovarian cancer is the leading cause of death from gynecological malignancies among women in the United States $(1,2)$. Effective chemotherapeutic regimens are available for the treatment of ovarian cancer including platinum-based regimens in combination with taxanes and other agents, however the efficacy of these drugs are often hampered by the tumors intrinsic or acquired drug resistance (3-5). Thus, new or improved modality for ovarian cancer therapy is urgently required.

A variety of anti-cancer drugs are either natural products or natural product derivatives (6). Natural dietary polyphenols such as resveratrol (grape), curcumin (turmeric spice) and epigallocatechin-3-gallate (EGCG; green tea), have shown promising chemotherapeutic activities against various types of cancer (7-9). In the present study we describe the effect of cranberry proanthocyanidin (PAC) extracts on ovarian cancer cells and the effects on angiogenesis in vitro. The North American cranberry (Vaccinium macrocarpon) is rich in polyphenolic constituents with flavonols, anthocyanins and PAC with A-type linkage. PACs are naturally occurring oligomeric flavan-3-ols found in fruits and nuts where they function as protective barriers against herbivory activity, pathogens and insects $(10,11)$. The beneficial effects of PAC have been reported against cardiovascular disease, bacterial infection, inflammation and skin complications (12-16). Moreover, recent studies have demonstrated the therapeutic potential of PAC in vivo and in vitro for the treatment of a wide spectrum of tumor types, including colorectal cancers, lung, brain, prostate, esophagus, oral and breast cancer (17-23). Due to difficulties in isolation of bioactive constituents studies with cranberry extracts in cancer treatment and on cellular response mechanisms have been limited. We recently succeeded in isolating cranberry PACs of a particular oligomeric range and observed specific cytotoxicity of this composition to ovarian cancer cells, prostate cancer and neuroblastoma cell lines (24).

Of high interest are the anti-angiogenic properties of berry products (25). Angiogenesis, or the formation of new blood 
vessels from existing ones, promotes tumor metastasis and ascites formation and significantly contributes to poor outcomes in ovarian cancer (26). Grape seed PAC were shown to prevent tumor metastasis in a breast cancer mouse model (27). PAC extracts from Japanese quince fruit and grape seed PACs inhibited MMP-2 and MMP-9 matrix metalloproteinase activities and expression respectively $(28,29)$. Despite accumulating evidence indicating that PACs are potent candidates for cancer treatment, their underlying mechanisms of action remain to be determined. In the present study we describe various modes of action that cranberry PAC-1 oligomers exert in ovarian cancer cells and endothelial cells in vitro. Elucidation of mechanisms of action may provide the opportunity to develop the utilization of specific PACs in the treatment of ovarian cancer in combinational or single-agent therapy.

\section{Materials and methods}

Cell lines, cell culture and materials. SKOV-3 cells (human ovarian adenocarcinoma) were purchased from ATCC (Manassas, VA) and cultured in Dulbecco's modified Eagle's medium (DMEM) supplemented with bovine calf serum or fetal calf serum $(10 \%)$, penicillin $(100 \mathrm{U} / \mathrm{ml})$ and streptomycin $(100 \mu \mathrm{g} / \mathrm{ml})$. Human umbilical vein endothelial cells (HUVEC) were purchased from Lonza (Walkersville, MD) and grown in endothelial growth medium (EGM)-2. Cells were cultured at $37^{\circ} \mathrm{C}$ with $5 \% \mathrm{CO}_{2}$ in a humidified incubator. Oligomeric proanthocyanidin fractions (PAC-1) from cranberry were obtained as previously described (24). Phenylmethylsulfonyl fluoride, glutathione, propidium iodide and rhodamine 123 were purchased from Sigma-Aldrich (Madison, WI) and carboxy- $\mathrm{H}_{2}$ DCFDA from Invitrogen (Carlsbad, CA). The glutathione stock solution was prepared in distilled water and the $\mathrm{pH}$ was adjusted to 7.3 by $\mathrm{NaOH}$ solution before use.

Cell viability and BrdU incorporation assay. Cells were seeded into a 96-well microtiter plate $\left(1 \times 10^{4} /\right.$ well $)$ in complete medium, allowed to attach at $37^{\circ} \mathrm{C}$ with $5 \% \mathrm{CO}_{2}$, in a humidified incubator. Cells were treated as indicated (Result Section) with PAC-1 dissolved in dimethyl sulfoxide (DMSO). Following drug treatment, cell viability was analyzed by the CellTiter 96 AQueous One Solution Assay (Promega Corp., Madison, WI) or proliferation analyzed using a Cell Proliferation ELISA/BrdU kit (Roche Applied Science, Indianapolis, IN) to measure BrdU incorporation of cells. Data were acquired at $492 \mathrm{~nm}$ (cell viability) or at $450 \mathrm{~nm}$ (BrdU incorporation) with a Multiskan RC microplate reader (Thermo Fisher Scientific Inc., Waltham, MA) and are expressed as the mean of the triplicate determinations $(\mathrm{X} \pm \mathrm{SD})$ of a representative experiment in \% of absorbance by samples with untreated cells $(=100 \%)$.

Cell cycle analysis. SKOV-3 cells $\left(3 \times 10^{5}\right)$ were seeded into the wells of 6-well plate and treated with various concentrations of PAC-1 $(25-75 \mu \mathrm{g} / \mathrm{ml}, 24 \mathrm{~h})$. The cells were collected, fixed by gradually adding ice-cold $70 \%$ ethanol solution and stained in a buffer solution containing propidium iodide $(100 \mu \mathrm{g} / \mathrm{ml})$, sodium citrate $(1 \mathrm{mg} / \mathrm{ml})$, Triton X-100 $(3 \mu \mathrm{l} / \mathrm{ml})$ and RNase $(200 \mu \mathrm{g})$. Data were acquired by a BD FACSort flow cytometer using CellQuest software (BD Immunocytometry Systems, San
Jose, CA) and analyzed by ModFit LT software (Verity Software House, Inc., Topsham, ME).

Determination of the mitochondrial membrane depolarization potential $\left(\Delta \Psi_{m}\right)$. Loss of $\Delta \Psi_{\mathrm{m}}$ was quantitatively determined by rhodamine 123 staining, a cationic dye which localizes in the mitochondria of viable cells. Cells were seeded into each well of a 6 -well plate $\left(3.0 \times 10^{5}\right)$ and incubated with vehicle or PAC-1 $(50 \mu \mathrm{g} / \mathrm{ml})$ for $24 \mathrm{~h}$, the last $30 \mathrm{~min}$ under staining with rhodamine $123(13 \mu \mathrm{M})$. Cells were harvested and re-suspended in medium containing propidium iodide $(7.5 \mu \mathrm{M})$. Data were acquired by a BD FACSort flow cytometer using CellQuest software (BD Immunocytometry Systems) and analyzed by ModFit LT software (Verity Software House, Inc.).

Detection of intracellular reactive oxygen species (ROS). ROS generation by PAC-1 was measured by flow cytometry using carboxy- $\mathrm{H}_{2} \mathrm{DCFDA}$ dye as probe. Carboxy- $\mathrm{H}_{2}$ DCFDA is the acetylated form of a reduced fluorescein-derivative that is cellpermeable and becomes fluorescent in the presence of hydrogen peroxide $\left(\mathrm{H}_{2} \mathrm{O}_{2}\right)$, hydroxyl radical $\left.(\mathrm{HO})^{\circ}\right)$, and peroxyl radical (ROO'). SKOV-3 cells $\left(3 \times 10^{5}\right)$ were seeded into each well of 6 -well plate and treated under the conditions indicated. Cells were stained with carboxy-H $\mathrm{H}_{2} \mathrm{DCFDA}(25 \mu \mathrm{M})$ for $30 \mathrm{~min}$ at $37^{\circ} \mathrm{C}, 5 \% \mathrm{CO}_{2}$. Data were acquired by a BD FACSort flow cytometer using CellQuest software (BD Immunocytometry Systems) and analyzed by ModFit LT software (Verity Software House, Inc.).

Western blot analysis. Cells were lysed with cell extraction buffer (BioSource International, Inc., CA) supplemented with phenylmethylsulfonyl fluoride and a protease inhibitor cocktail (Sigma-Aldrich, St. Louis, MO). The protein concentration of the lysates was quantified using the Bio-Rad DC protein assay kit (BioRad, Hercules, CA). Protein electrophoresis was performed by using the NuPAGE Gel system (Invitrogen). Briefly, each lysate sample was mixed with LDS sample buffer and sample reducing buffer, incubated at $70^{\circ} \mathrm{C}$ for $10 \mathrm{~min}$, loaded and separated by using the Xcell SureLock ${ }^{\mathrm{TM}}$ mini-cell electrophoresis system (Invitrogen) on NuPAGE 4-12\% Tris-Bis Gel in NuPAGE MES SDS running buffer or NuPAGE 3-8\% Tris-Acetate Gel in Novex TA SDS running buffer, transferred onto a PVDF membrane, blocked with 5\% non-fat dry milk in PBS-Tween or TBS-Tween buffer and probed against various primary antibodies (cleaved PARP no. 9541, cleaved caspase-3 no. 9661 , cleaved caspase-7 no. 9491 , caspase- 8 no. 9746 , AKT no. 9272, phospho-AKT no. 4058, VEGF-R2 no. 2479, phospho-VEGF-R2 no. 2478; Cell Signaling Technologies, Danvers, MA), or GAPDH antibody (sc-47724; SantaCruz Biotechnology, Santa Cruz, CA). The bands were visualized using horseradish peroxidase-conjugated secondary antibody (against rabbit IgG by Cell Signaling Technologies; against mouse IgG by SantaCruz Biotechnology), an ECL Plus chemiluninescence kit (GE Healthcare Life Sciences; Piscataway, NJ), and documented by autoradiography (F-Bx810 Film, Phenix, Hayward, CA).

Caspase-3/7 activity assay. The activities of caspase-3 and -7 were measured using the Apo-One Homogeneous caspase-3/7 assay kit (Promega). SKOV-3 cells were plated in a 96-well 
white plate and incubated with vehicle or PAC-1 $(50 \mu \mathrm{g} / \mathrm{ml})$ for $24 \mathrm{~h}$. After treatment, cells were lysed with buffer containing caspase substrate bis-Z-DEVD-rhodamine 100. The lysis was enhanced by a freeze-thaw cycle. The plate was further incubated at room temperature for $5 \mathrm{~h}$ until analyzed. Data were obtained from a SpectraMax Gemini EM microplate reader (Molecular Devices, Silicon Valley, CA) at $499_{\mathrm{ex}} / 521_{\mathrm{em}} \mathrm{nm}$.

Tube formation assay. A 96-well plate was coated with $50 \mu 1$ of basement membrane extract (Trevigen, Inc. Gaithersburg, MD) before seeding of HUVEC cells $\left(1.0 \times 10^{4}\right)$ in EGM-2 medium $(100 \mu \mathrm{l})$ containing either vehicle or PAC-1 $(12.5 \mu \mathrm{g} / \mathrm{ml})$ and incubation at $37^{\circ} \mathrm{C}$ with $5 \% \mathrm{CO}_{2}$. After incubation, capillarylike/tube formation of HUVEC was assessed and the images were taken with an inverted Nikon Eclipse TE2000-E microscope and a $4 \mathrm{x}$ objective.

Statistical analysis. Differences between the means of samples were evaluated by the Student's t-test using Microsoft Excel (Seattle, WA). $\mathrm{P}<0.001$ was considered statistically significant.

\section{Results}

Cranberry PAC-1 is a potent cytotoxic agent to ovarian cancer cells. A comprehensive activity-guided fractionation of the American cranberry was obtained via extraction, followed by Sephadex-LH20, MCI-Gel column chromatography and MALDI-TOF-MS characterization leading to the identification of PAC-1, an isolate of A-type oligomeric cranberry proanthocyanidins with selective cytotoxic properties (24). We first verified previously observed anti-proliferative and cytotoxic effects of PAC-1 in platinum-resistant SKOV-3 ovarian cancer cells via a colorimetric BrdU incorporation and an MTS [3-(4,5-dimethylthiazol-2-yl)-5-(3-carboxymethoxyphenyl)-2-(4-sulfophenyl)-2H-tetrazolium] assay. SKOV-3 cells were treated with a series of concentrations of PAC-1 $(12.5-100 \mu \mathrm{g} / \mathrm{ml})$ for $24 \mathrm{~h}$ before the assays were carried out. PAC-1 reduced the viability (Fig. 1, left panel) and proliferation (Fig. 1, right panel) of SKOV-3 cells in a dose-dependent manner. At a concentration of $50 \mu \mathrm{g} / \mathrm{ml}$ viability was reduced by $39.1 \%$ and proliferation by $64.5 \%$, at a concentration of $75 \mu \mathrm{g} / \mathrm{ml}$ viability was reduced by $66 \%$ and proliferation by $84.9 \%$ and at a concentration of $100 \mu \mathrm{g} / \mathrm{ml}$ viability was reduced by $81.8 \%$ and proliferation by $92.4 \%$. Upon comparison of the effectivity profile in these two distinct assays significant cytostatic properties of PAC-1 were not found suggesting that the cytotoxic effects are the primary determinants of the potential effects.

In a previous study we showed that treatment of ovarian cancer cells with PAC-1 resulted in morphological changes characteristic for apoptotic events (24). To understand the mechanism involved in the cellular response to the drug we examined the mitochondrial transmembrane depolarization potential $\left(\Delta \Psi_{\mathrm{m}}\right)$ of SKOV-3 cells by flow cytometry. The cells were double-stained with PI (chromatin stain in cells with ruptured cell membrane) and rhodamine 123 which accumulates in mitochondria and directly correlates to the integrity of $\Delta \Psi_{\mathrm{m}}$. The majority (94.1\%) of untreated SKOV-3 cells were viable (Fig. 2A, left panel, Q4) as depicted by uptake of rhodamine 123 without nuclear PI staining. In contrast, PAC-1

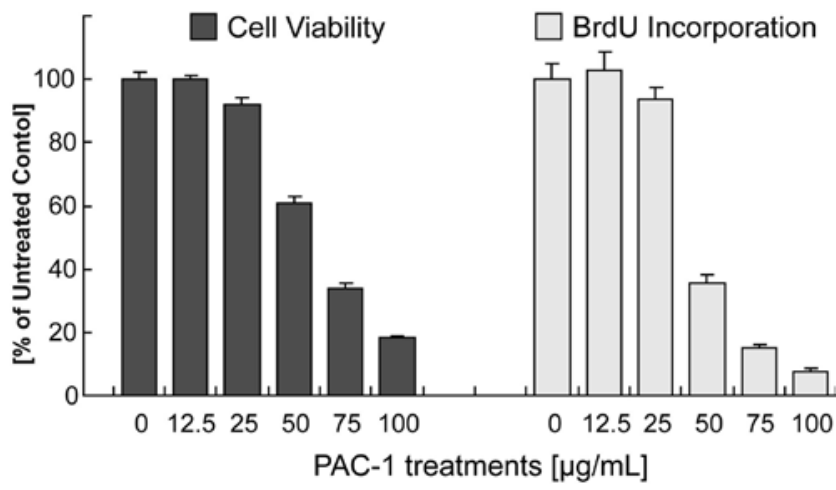

Figure 1. Anti-proliferative and cytotoxic effects of cranberry PAC-1 in ovarian cancer cells. The cytotoxic effect of PAC-1 on SKOV-3 cells was evaluated by using the MTS viability assay (left panel) and anti-proliferative effects were measured by BrdU incorporation into DNA (right panel) as described in Materials and methods. Cells were treated with vehicle or varying concentrations of PAC-1 (12.5-100 $\mu \mathrm{g} / \mathrm{ml})$ for $24 \mathrm{~h}$. Data are expressed as the mean of the triplicate determinations $(\mathrm{X} \pm \mathrm{SD})$ in percent of absorbance of untreated cells $(=100 \%)$.

treatment $(50 \mu \mathrm{g} / \mathrm{ml}, 24 \mathrm{~h})$ led to integrity loss of $42.6 \%$ of the cells (Fig. 2A right panel, Q1 + Q2 + Q3). Under the treatment, loss of the $\Delta \Psi_{\mathrm{m}}$ was observed in $36.9 \%$ of cells $(\mathrm{Q} 1+\mathrm{Q} 3)$ with $29.7 \%$ of the cells still possessing intact cell membranes (Q3) and $7.2 \%$ with ruptured cell membrane. These data suggest that PAC-1 targets and disrupts mitochondrial functions of SKOV-3 cells linked to the onset of apoptosis.

PAC-1 causes $G_{2} / M$ cell cycle arrest in ovarian cancer cells. Previously, PAC complexes were reported to block cell cycle progression (30). We analyzed the concentration-dependent effect of PAC-1 on the ovarian cancer cell cycle via flow cytometry of propidium iodide (PI) stained SKOV-3 cells (Fig. 2B and $\mathrm{C}$ ). PAC-1 treatment for $24 \mathrm{~h}$ caused $\mathrm{G}_{2} / \mathrm{M}$-phase arrest in a dose-dependent manner. The $\mathrm{G}_{2} / \mathrm{M}$ population increased from $9.9 \%$ of untreated cells to $43.3 \%$ for cells treated with PAC-1 at $75 \mu \mathrm{g} / \mathrm{ml}$ (Fig. 2C). PAC-1 at $25 \mu \mathrm{g} / \mathrm{ml}$ led to retention of $15.8 \%$ and at $50 \mu \mathrm{g} / \mathrm{ml}$ of $33.0 \%$ of cells in $\mathrm{G}_{2} / \mathrm{M}$ phase. Accordingly the populations of $\mathrm{G}_{1}$ and $\mathrm{S}$-phase decreased from $50 \%\left(\mathrm{G}_{1}\right)$ and $40.2 \%(\mathrm{~S})$ for untreated cells to $34.1 \%$ $\left(\mathrm{G}_{1}\right)$ and $22.5 \%(\mathrm{~S})$ for $75 \mu \mathrm{g} / \mathrm{ml}$ PAC-1-treated SKOV-3. We observed a minor increase only in the sub-diploidal (apoptotic) sub- $\mathrm{G}_{1}$ phase of cells even after $75 \mu \mathrm{g} / \mathrm{ml}$ PAC- 1 treatment (1.6\% background for untreated cells, $9.6 \%$ for treated cells). As often seen during cell cycle analysis necrotic and apoptotic cells with substantially affected morphology caused by cytotoxic drugs are not measured using gating of standardized cell population. Accordingly, Our findings demonstrate that PAC-1 is a drug that possesses cytotoxic as well as cytostatic features and promotes an arrest of ovarian cancer cells in $\mathrm{G}_{2} / \mathrm{M}$ phase.

PAC-1 causes elevated intracellular reactive oxygen species (ROS) generation correlated to cytotoxicity in ovarian cancer cells. We determined whether PAC-1 affects the level of intracellular ROS in SKOV-3 cells. The production of ROS was measured by flow cytometry using oxidant-sensitive carboxy$\mathrm{H}_{2}$ DCFDA dye. As depicted in Fig. 3A, cells following PAC-1 treatment $(75 \mu \mathrm{g} / \mathrm{ml}, 24 \mathrm{~h})$, displayed an increase in cellular ROS levels (peak shift in relative fluorescence intensity). In 
A

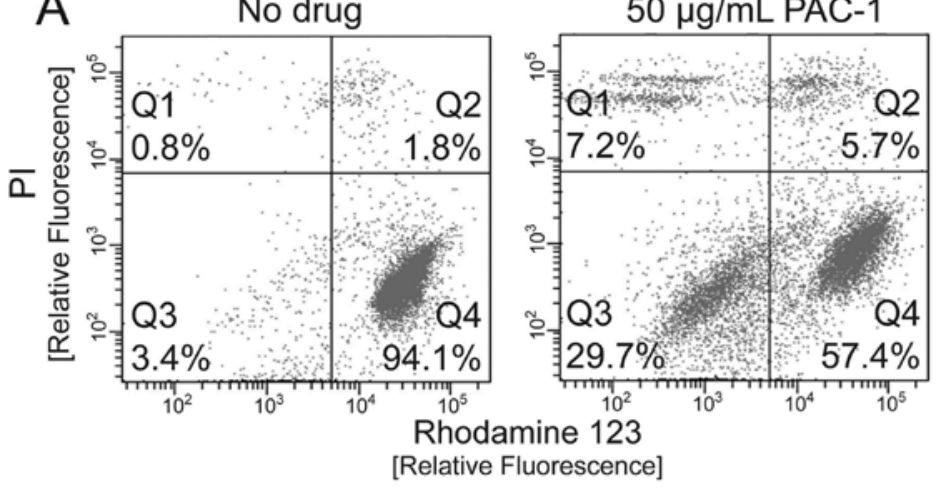

B No drug

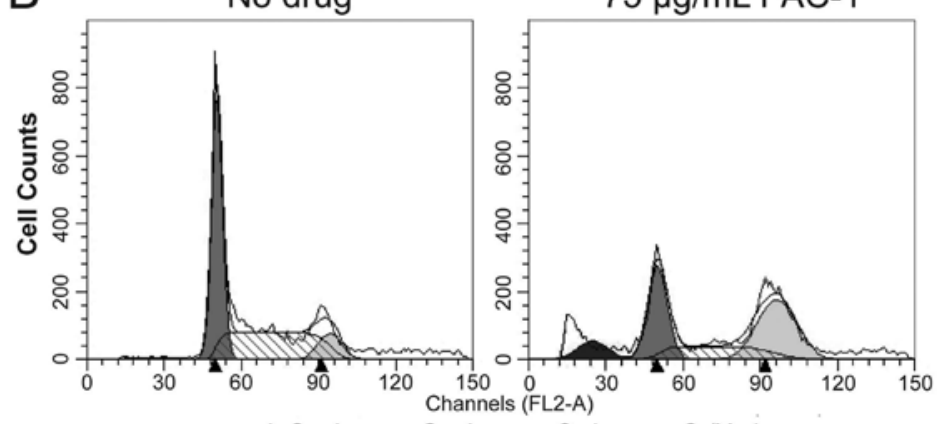

घub-G ${ }_{1}$-phase $\square G_{1}$-phase $\nabla S$-phase $\square G_{2} / M$-phase

\begin{tabular}{|c|c|c|c|c|c|}
\hline & & sub- $\mathrm{G}_{1}$ & $\mathrm{G}_{1}$ & s & $\mathrm{G}_{2} / \mathrm{M}[\%]$ \\
\hline \multicolumn{2}{|c|}{ No drug } & 1.57 & 49.98 & 40.15 & 9.86 \\
\hline \multirow[t]{3}{*}{ PAC-1 [ $\mu \mathrm{g} / \mathrm{mL}]$} & 25 & 1.31 & 53.22 & 31.00 & 15.77 \\
\hline & 50 & 5.54 & 43.42 & 23.57 & 33.00 \\
\hline & 75 & 9.6 & 34.13 & 22.54 & 43.32 \\
\hline
\end{tabular}

Figure 2. Determination of the mitochondrial membrane depolarization potential $\left(\Delta \Psi_{\mathrm{m}}\right)$ and cell cycle progression in PAC-1-treated ovarian cancer cells. (A) Effect of PAC-1 treatment on $\Delta \Psi_{\mathrm{m}}$. SKOV-3 cells were treated with vehicle or PAC-1 $(50 \mu \mathrm{g} / \mathrm{ml})$ for $24 \mathrm{~h}$ and changes of $\Delta \Psi_{\mathrm{m}}$ (mitochondria-specific rhodamine 123 dye; $x$-axis) and of cell membrane damage (propidium iodide dye; PI, y-axis) analyzed as described in Materials and methods. (B and C) Effect of PAC-1 treatment on cell cycle. SKOV-3 cells were treated with PAC-1 $(25-75 \mu \mathrm{g} / \mathrm{ml})$ for $24 \mathrm{~h}$. Cell cycle analysis following PI intercalation into the cellular chromatin was performed by FACS as described in Materials and methods. Data are presented as either relative fluorescence intensity of the apoptotic sub-G1-, G1-, S- and G2/M-phase population in a 2-dimensional FACS profile (B; example shown for PAC-1 treatment at $75 \mu \mathrm{g} / \mathrm{ml}$ after $24 \mathrm{~h}$ incubation) or in a table (C).

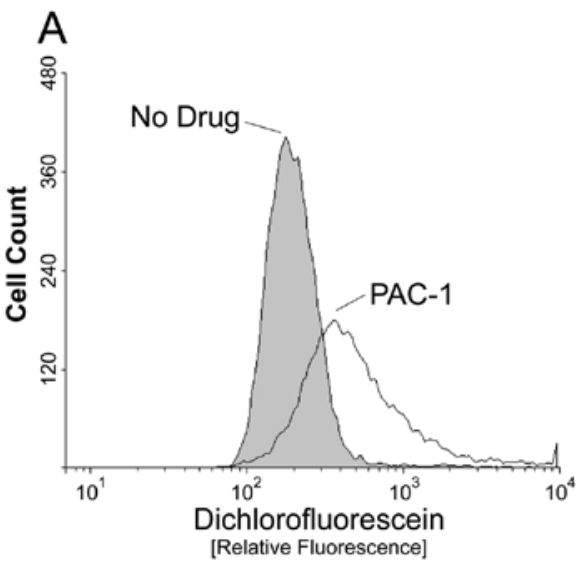

B

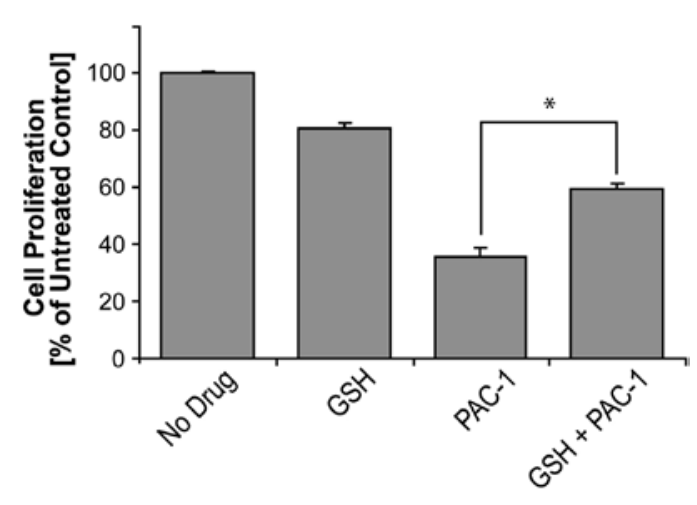

Figure 3. PAC-1 induced generation of intracellular-reactive oxygen species (ROS) in ovarian cancer cells. (A) Generation of ROS after PAC-1 treatment. SKOV-3 cells were treated with PAC-1 $(75 \mu \mathrm{g} / \mathrm{ml}, 24 \mathrm{~h})$. ROS levels of cells were determined by FACS by quantifying the fluorescence of the ROS-sensitive probe (carboxy- $\mathrm{H}_{2}$ DCFDA) as described in Materials and methods. (B) Suppression of anti-proliferative effects of PAC-1 by antioxidant glutathione (GSH). SKOV-3 cells were incubated with PAC-1 alone $(75 \mu \mathrm{g} / \mathrm{ml})$ or together with glutathione $(15 \mathrm{mM})$ for $24 \mathrm{~h}$. Cell proliferation was measured by BrdU incorporation (Materials and methods). Data are expressed as the mean of the triplicate determinations $(\mathrm{X} \pm \mathrm{SD})$ in percent of absorbance of untreated cells $(=100 \%)$. 


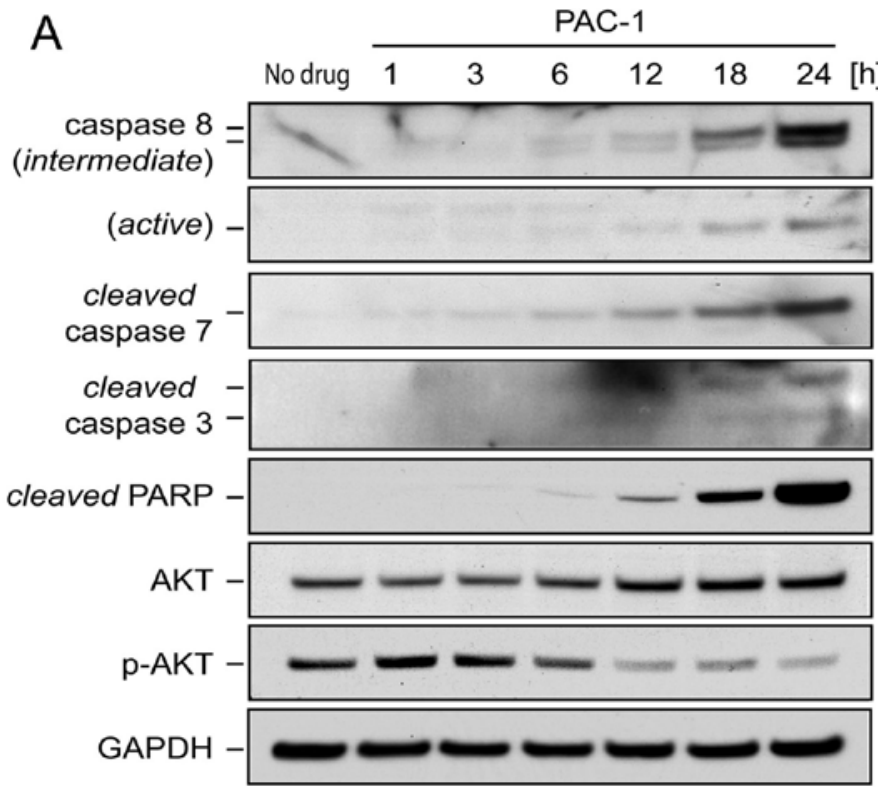

B

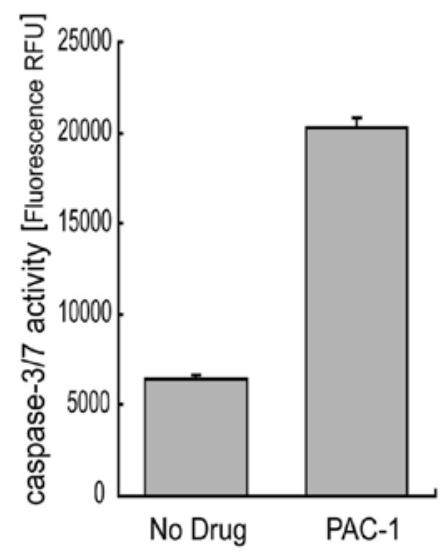

Figure 4. Effects of PAC-1 on the expression of apoptotic and pro-survival markers in ovarian cancer cells. (A) Activation of caspases and deactivation of PARP and AKT after PAC-1 treatment. SKOV-3 cells were treated with vehicle or PAC-1 (50 $\mu \mathrm{g} / \mathrm{ml})$ for varying times as indicated. The protein levels in cellular lysates of cleaved/activated caspases, cleaved/deactivated PARP, AKT or phospho-AKT were determined by Western blot analysis as described in Materials and methods. As an internal standard for equal loading blots were probed with an anti-GAPDH antibody. (B) Effect of PAC-1 on caspase-3/7 activity. SKOV-3 cells were treated with vehicle or PAC-1 $(50 \mu \mathrm{g} / \mathrm{ml})$ for $24 \mathrm{~h}$ and lysed with a buffer containing the caspase-3/7 substrate, bis-(Z-Asp-Glu-Val-Asp; Z-DEVD)rhodamine 110 and further incubated for $5 \mathrm{~h}$. Fluorescence of each well was measured at an excitation/emission wavelength of $499 / 521 \mathrm{~nm}$. Data are expressed in relative fluorescence units (RFU; $y$-axis) as the mean of the triplicate determinations $(\mathrm{X} \pm \mathrm{SD})$.

a cell proliferation assay SKOV-3 cells were incubated with PAC-1 $(75 \mu \mathrm{g} / \mathrm{ml}, 24 \mathrm{~h})$ with or without co-treatment by antioxidant glutathione (GSH). PAC-1 treatment alone reduced cell proliferation by $64.1 \%$ (Fig. 3B). Even though exposure to a high concentration of GSH (15 mM, $24 \mathrm{~h})$ per se led to reduced proliferation by $19.3 \%$, co-treatment of GSH with PAC-1 diminished the effect of PAC-1 by $23.6 \%$. The restoration from the drug effect by an antioxidant indicates that the increased ROS generation induced by PAC-1 is an essential mechanism of cytotoxic action in SKOV-3 ovarian cancer cells.

PAC-1 activates apoptotic markers and modulates the AKT survival pathway. To gain insight into the cytotoxic mechanisms of PAC-1 in ovarian cancer cells we analyzed by Western blot analysis the activation/inactivation of various apoptotic markers such as caspases and PARP as well as the expression and activation/phosphorylation-status of AKT. AKT activation is frequently found in ovarian cancer (31) and directly or indirectly affects multiple downstream targets that function to inhibit many pro-apoptotic proteins including caspases (32). As shown in Fig. 4A, PAC-1 at a concentration of $50 \mu \mathrm{g} / \mathrm{ml}$ exhibited time-dependent activation of initiator (caspase-8) and effector caspases (caspase-3 and -7) starting within $12 \mathrm{~h}$ of treatment of SKOV-3 cells. Immunoblotting of cellular lysates also revealed that PAC-1 caused a rapid (within $6 \mathrm{~h}$ ) and sustained inactivation/cleavage of DNA repair factor PARP (Fig. 4A). To verify the critical role of caspases 3 and 7 in PAC-1-induced apoptosis, their activities were assessed by measuring proteolytic cleavage of the substrate peptide DEVD. As shown in Fig. 4B, PAC-1 $(50 \mu \mathrm{g} / \mathrm{ml}, 24 \mathrm{~h})$ induced an almost 4 -fold increase in caspase $3 / 7$ activity in SKOV-3 cells.
In addition, we found that PAC-1 treatment $(50 \mu \mathrm{g} / \mathrm{ml}, 24 \mathrm{~h})$ in SKOV-3 cells resulted in a clear reduction of AKT activation when compared to the level of vehicle-treated controls starting $6 \mathrm{~h}$ after treatment initiation and reaching background signals after $24 \mathrm{~h}$ (Fig. 4A). Expression of inactive AKT was not significantly altered through PAC-1 treatment during the incubation period $(24 \mathrm{~h})$. Through densitometric assessment of the immunoblot bands, the ratios of phosphorylated AKT versus total AKT were found to be $0.29,0.34$ and 0.23 for their respective treatment periods $(12,18$ and $24 \mathrm{~h})$ as compared to 1.03 of the ratio of the control. These results suggested that suppression of AKT signaling is a putative therapeutic target of PAC-1 in SKOV-3 ovarian cancer cells.

PAC-1 decreases endothelial cell viability correlated to AKT inactivation. Angiogenesis is an essential biological process not only associated with embryogenesis and wound repair but also tumor development. To assess the therapeutic potential of PAC-1 as an inhibitor of angiogenesis we tested the effects of PAC-1 on endothelial cell viability in vitro. Human umbilical vein endothelial cells (HUVEC) were treated with various concentrations of PAC-1 (0-100 $\mu \mathrm{g} / \mathrm{ml}, 6 \mathrm{~h})$. As shown, dose-dependent reduction of cell viability was observed upon PAC-1 treatments (Fig. 5A) with an $\mathrm{IC}_{50}$ between $25-50 \mu \mathrm{g} / \mathrm{ml}$. As shown above (Fig. 4A), PAC-1 (50 $\mu \mathrm{g} / \mathrm{ml}, 24 \mathrm{~h})$ down-regulated activation of the AKT signal in SKOV-3 ovarian cancer cells. Similarly, as shown in immunoblotting of PAGE-separated HUVEC cell lysates PAC-1 exhibited suppression of AKT phosphorylation in a dose-dependent manner in endothelial cells (Fig. 5B). Interestingly, comparable AKT inactivation in HUVEC cells required PAC-1 concentrations of only $6.25 \mu \mathrm{g} / \mathrm{ml}$ thus 8 -fold 

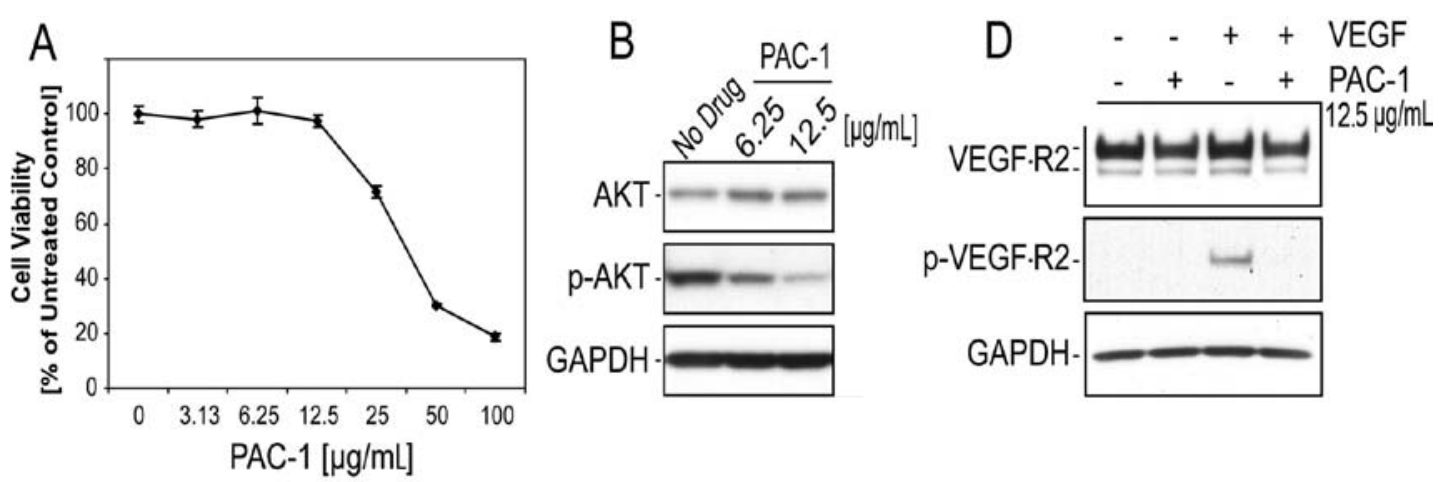

C

PAC-1 concentration $[\mu \mathrm{g} / \mathrm{mL}]$

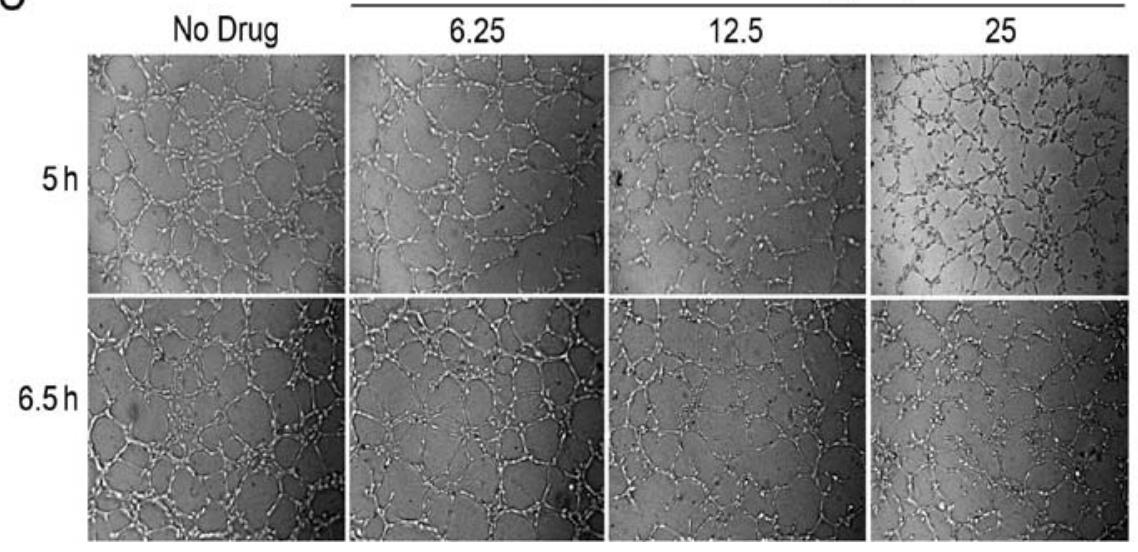

Figure 5. (A) Effect of PAC-1 on viability, tube formation and AKT, VEGFR expression of endothelial cells. (A) Cytotoxicity of PAC-1. HUVEC cells were treated with vehicle or various concentrations of PAC-1 (3.13-100 $\mu \mathrm{g} / \mathrm{ml})$ for $6 \mathrm{~h}$. At the end of the treatment cells the MTS assay was carried out (Materials and methods). Data are expressed as the mean of the triplicate determinations $(\mathrm{X} \pm \mathrm{SD})$ in percent of absorbance of untreated cells $(=100 \%)$. (B) Effects of PAC-1 on expression and activation of pro-survival marker AKT. HUVEC cells were treated with vehicle or PAC-1 for $24 \mathrm{~h}$ at the concentrations as indicated The protein levels in cellular lysates of AKT or phospho-AKT were determined by Western blot analysis as described in Materials and methods. As an internal standard for equal loading blots were probed with an anti-GAPDH antibody. (C) Inhibition of endothelial capillary-like/tube formation by PAC-1. HUVEC cells were plated on the surface of basement membrane extract, treated with vehicle or PAC-1 $(6.25,12.5,25 \mu \mathrm{g} / \mathrm{ml})$ in complete media as described in Materials and methods for 5 or $6.5 \mathrm{~h}$ and analyzed by light microscopy. Images obtained from a representative experiment are shown. (D) Effects of PAC-1 on VEGF-stimulated receptor phosphorylation. HUVECs were treated with vehicle or PAC-1 at indicated doses for 30 min prior to VEGF-stimulation for 2 min. The protein levels in lysates of VEGF-R2 or phospho-VEGF-R2 were determined by Western blot analysis.

lower concentrations of this compound when compared to SKOV-3.

PAC-1 inhibits tube-formation and blocks vascular endothelial growth factor (VEGF)-stimulated receptor phosphorylation in endothelial cells. Based on the findings described above, a tube formation assay was performed to assess if PAC-1 might block cancer development through inhibition of angiogenesis at sub-cytotoxic concentrations. HUVEC cells were incubated on extracellular basement membrane extract matrix (Materials and methods) and treated with PAC-1 $(6.25,12.5$ or $25 \mu \mathrm{g} / \mathrm{ml}$; for 5 or $6.5 \mathrm{~h}$ ) before evaluation by light microscopy. As depicted in Fig. 5C, vehicle-treated HUVEC developed capillary/tube-like structures with interconnecting networks within $5 \mathrm{~h}$ that were further augmented after $6.5 \mathrm{~h}$ of incubation. However, PAC-1 $(12.5 \mu \mathrm{g} / \mathrm{ml})$ markedly disrupted tube formation and caused defects in the network formation. Proliferation, migration and tube formation of endothelial cells is directly linked and enhanced by VEGF functions with VEGF-R2 being the primary regulatory receptor (33). We evaluated the effects of PAC-1 treatment on VEGF-stimulated activation of VEGF-R2 in HUVEC cells via immunoblotting using an antibody detecting phosphorylation of VEGF-R2 at $\mathrm{Tyr}^{1175}$. $\mathrm{Ty}^{1175}$ has been described as one of the major auto-phosphorylation sites of VEGF-R2 (33). A detection antibody against unphosphorylated VEGF-R2 was employed to determine the basic expression level of inactive VEGF-R2. Cells were treated with vehicle or PAC-1 $(12.5 \mu \mathrm{g} / \mathrm{ml}, 30 \mathrm{~min})$ followed by VEGF-stimulation (2 $\mathrm{ng} / \mathrm{ml}, 2 \mathrm{~min}$ ). Expression levels of inactive VEGF-R2 in samples independent of VEGF and/or PAC-1 treatment remained comparable (Fig. 5D). Contrary to untreated cells that did not reveal receptor activation, VEGF-stimulation led to phosphorylation of VEGF-R2 (Fig. 5D). However, when the cells were co-treated with VEGF and PAC-1, phosphorylation of VEGF-R2 was blocked. Accordingly, PAC-1 could provide therapeutic value by blocking VEGF functions in endothelial cells thus affecting fast growing tumors.

\section{Discussion}

Natural products derived from dietary fruits and vegetables are promising therapeutic agents for cancer prevention and treatment. Cranberry phytochemicals such as flavonols and PACs possess anti-neoplastic effects against a variety of cancer 
types, including colon, prostate, bladder, stomach and breast tumors (34-37). However, little is known about the underlying mechanism(s) of anti-cancer properties of cranberry extracts. A recent report from our laboratory revealed that an HPLC-purified and MS-characterized PAC-1 fraction from cranberry displays potent anti-cancer activities against platinum drug-resistant SKOV-3 ovarian cancer cells (24). To further expand these initial findings, in the present study we have characterized various mechanisms that mediate the anti-proliferative and cytotoxic features of PAC-1 in ovarian cancer cells as well as endothelial cells since angiogenesis is crucial for tumor growth, invasion and metastasis (38). As model cell lines we chose SKOV-3 (ovarian adenocarcinoma) cells that are resistant to clinically relevant concentrations of drugs such as cisplatin and adriamycin (ATCC; www.atcc.org) and HUVEC (endothelial umbilical vein) cells which are used in a wide spectrum of biological and biochemical assays conducted during drug discoveries.

Cell death of ovarian cancer cells as a result of treatment with cranberry PAC is an apoptotic event. Upon PAC-1 treatment effector as well as initiator caspases including caspase-8, a key player in the extrinsic/death receptor pathway of apoptosis, were activated. PAC-1 treatment lead to degradation of DNA repair factor PARP, the loss of $\Delta \Psi_{\mathrm{m}}$ which is an indicator of irreversible apoptotic responses of drug-treated cells (39) and inactivation of pro-survival factor AKT. Similarly, B-type PACs from grape seeds have been shown to suppress Pi3K/ AKT signaling in skin and colon cancer cells $(40,41)$. This pathway is particularly important in the drug response of tumor cells, such as ovarian cancer, that display activation of AKT and other components or low expression of tumor suppressors (e.g. PTEN, a Pi3K/AKT cascade regulator) $(31,42)$. AKT activity has been shown to correlate with poor prognosis in patients suffering ovarian cancer (43). The Pi3K/ AKT signaling cascade directly or indirectly inhibits many pro-apoptotic proteins including caspases or transcription factors that activate pro-apoptotic genes (32) and is linked to attenuation of cell cycle arrests upon induced DNA damage (44). Targeting the Pi3K/AKT/mTOR pathway by agents such as PAC-1 has been suggested as a promising treatment option in ovarian tumors or cell lines such as SKOV-3 that are highly resistant to conventional chemotherapy $(31,45,46)$.

We described the ability of cranberry PAC to cause an arrest of ovarian cancer cells in $\mathrm{G}_{2} / \mathrm{M}$ phase of the cell cycle. Cells in $\mathrm{G}_{2} / \mathrm{M}$ phase are known to be radiation-sensitive (47), suggesting that PAC-1 enhances radiotherapy effectiveness. Even at concentrations below the $\mathrm{IC}_{50}$, PAC-1 delayed progression of SKOV-3 cells through $\mathrm{G}_{2} / \mathrm{M}$ and reduced the number of cells in S-phase. Regulators of the cell cycle machinery are frequently altered in human cancer and transformed cells can be more sensitive to cyclin-dependent kinase (CDK) inhibition $(48,49)$. Based on the effects of PAC-1 on cell cycle progression, future studies would evaluate the role of this potential cancer therapeutic on specific cell cycle regulators $(50,51)$ in synchronized ovarian cancer, other cancer and non-transformed cell cultures. Targeting such checkpoints has been suggested as an alternative or supplemental approach to anti-cancer therapies $(52,53)$.

Although the underlying mechanism of many dietary products with anti-cancer features remains largely unclear, the generation of ROS by oligomeric PACs from hops (Humulus lupulus) has been linked to oxidative protein damage and induc- tion of colon cancer cell death (54). In addition, as shown in the present study PAC-1 treatment lead to excessive generation of ROS in SKOV-3 cells which was partially responsible for the drug-induced cell death. Consequently, cell treatment by an antioxidant attenuated PAC-1 induced cytotoxicity. Generally, ROS, by-products of the cellular metabolism (55), are tightly regulated in balance with cellular defensive antioxidants, such as catalase and SOD. However, further upregulation of cellular ROS, such as shown here after treatment with PAC-1 has been suggested to selectively target tumor tissue over normal cells $(56,57)$. Several studies have shown that ROS generation is one crucial effect of several chemotherapeutic drugs including daunorubicin, cyclophosphamide and fenretinide that are in clinical use or trials as anti-cancer drugs (58-60). PAC-1-mediated ROS generation may exert synergistic effects when combined with commonly used therapeutics or other agents, thought to modulate the antioxidant functions of cancer cells, for example 2-methoxyestradiol (SOD inhibitor) or buthionine-sulfoximine (inhibitor of glutathione/ GSH synthesis).

In addition to the concentration-dependent cytotoxic properties of PAC-1 in ovarian cancer $\left(\mathrm{IC}_{50}\right.$ of $\left.50 \mu \mathrm{g} / \mathrm{ml}\right)$, this agent displays anti-angiogenic activity at $12.5 \mu \mathrm{g} / \mathrm{ml}$ by blocking tube formation of endothelial cells. Several dietary-based agents including grape seed extracts have been reported to disturb endothelial cell growth (61). Angiogenesis plays pivotal roles in tumor progression and is believed to be governed by a balance of pro-angiogenic and anti-angiogenic factors (26). PAC-1 blocked VEGF-stimulated receptor phosphorylation in HUVEC cells, which correlated with the inhibition of tube-formation. VEGF is a specific mitogen for endothelial cells and a key regulator during tumor angiogenesis (62). VEGF receptor activation has been implicated in regulating proliferation, migration, as well as tube formation of endothelial cells (33) and the level of VEGF receptor expression in endothelial tissue has been shown to correlate with the disease severity in ovarian cancer (26). Similarly, VEGF production promotes ascites formation conveying poor outcome in patients with ovarian cancer. VEGF can be a target for pharmacologic intervention such as by immunoneutralization (63). The present report revealed that PAC-1 blocked VEGF-stimulated phosphorylation of the VEGF-R2 receptor (33) and blocked tube-formation by HUVEC cells suggesting that this agent may be of therapeutic value in the treatment of tumors. The inhibition of VEGF signaling by drugs, such as bevacizumab, has shown promising results in ovarian cancer (63). A significant feature of PAC-1 treated ovarian cancer as well as endothelial cells is the inactivation of pro-survival factor AKT. Endothelial cells can be desensitized to chemotherapy via a VEGF stimulated Pi3K/AKT-dependent mechanism (64) suggesting that PAC-1 can specifically unfold anti-neoplastic features by not only targeting the cancer cells (e.g. of ovarian tumors) but also by inhibition of angiogenic events in the tumor environment.

In summary, the present study suggests that highly purified PAC extracts from cranberry can be developed for single drug or combinational treatment of ovarian cancer. PAC-1, in its ability to raise ROS levels may exert synergistic effects when combined with other drugs thought to modulate the antioxidant functions of cells. The cytostatic effect of PAC-1 at sub-cytotoxic concentrations on the cell cycle might add to the potential therapeutic value of these natural products. Other 
features of PAC-1 as a potential anti-cancer drug include the suppression of pro-survival Pi3K/AKT signaling in ovarian cancer as well as in endothelial cells and block VEGF function in endothelial cells, which positively correlated with the inhibition of endothelial tube-formation. The cytotoxic effect on ovarian cancer cells and anti-angiogenic properties of cranberry PAC-1 suggest future toxicity and anti-tumor efficacy studies in animal models.

\section{Acknowledgements}

R.G.M. is partially supported by NCI grant no. 1 RO1 CA136491-01 and grants from Swim Across America. R.K.S. is partially supported by grants from Swim Across America. A.P.S. and N.V. are grateful to Mr Graham Gibson (Applied Biosystems) for his gift of the API-3000 LC-MS-MS instrument and to funding support from USDA-CREES (SRG 88-34155-3491).

\section{References}

1. Heintz APM, Odicino F, Maisonneuve P, Beller U, Benedet JL and Creasman WT: International Federation of Gynecology and Obstetrics 25th annual report. Carcinoma of the ovary. Int J Gyn Obst 83: 135-137, 2003.

2. American Cancer Society, Cancer Facts and Figures (www. cancer.org), 2011.

3. Piccart MJ, Bertelsen K, James K, Cassidy J, Mangioni C, Simonsen E, Stuart G, Kaye S, Vergote I, Blom R, Grimshaw R, Atkinson RJ, Swenerton KD, Trope C, Nardi M, Kaern J, Tumolo S, Timmers P, Roy JA, Lhoas F, Lindvall B, Bacon M, Birt A, Andersen JE, Zee B, Paul J, Baron B and Pecorelli S: Randomized intergroup trial of cisplatin-paclitaxel versus cisplatin-cyclophosphamide in women with advanced epithelial EOC: three-year results. J Natl Cancer Inst 92: 699-708, 2000.

4. Lamberth E, Gregory WM, Nelstrop AE and Rustin GL: Longterm survival in 463 women treated with platinum analogs for advanced epithelial carcinoma of the ovary: life expectancy compared to women of an age-matched normal population. Int J Gynecol Cancer 14: 772-778, 2004.

5. Leitao Jr MM, Hummer A, Dizon DS, Aghajanian C, Hensley M, Sabbatini P, Venkatraman E and Spriggs DR: Platinum retreatment of platinum-resistant EOC after nonplatinum therapy. Gynecol Oncol 91: 123-129, 2003.

6. Newman DJ and Cragg GM: Natural products as sources of new drugs over the last 25 years. J Nat Prod 70: 461-477, 2007.

7. Delmas D, Rébé C, Lacour S, Filomenko R, Athias A, Gambert P, Cherkaoui-Malki M, Jannin B, Dubrez-Daloz L, Latruffe N and Solary E: Resveratrol-induced apoptosis is associated with Fas redistribution in the rafts and the formation of a death-inducing signaling complex in colon cancer cells. J Biol Chem 278: 41482-41490, 2003.

8. Dhillon N, Aggarwal BB, Newman RA, Wolff RA, Kunnumakkara AB, Abbruzzese JL, Ng CS, Badmaev V and Kurzrock R: Phase II trial of curcumin in patients with advanced pancreatic cancer. Clin Cancer Res 14: 4491-4499, 2008

9. Shammas MA, Neri P, Koley H, Batchu RB, Bertheau RC, Munshi V, Prabhala R, Fulciniti M, Tai YT, Treon SP, Goyal RK, Anderson KC and Munshi NC: Specific killing of multiple myeloma cells by (-)-epigallocatechin-3-gallate extracted from green tea: biologic activity and therapeutic implications. Blood 108: 2804-2810, 2006.

10. de Rezende AA, Graf U, Guterres Zda R, Kerr WE and Spanó MA: Protective effects of proanthocyanidins of grape (Vitis vinifera L.) seeds on DNA damage induced by doxorubicin in somatic cells of Drosophila melanogaster. Food Chem Toxicol 47: 1466-1472, 2009.

11. Dixon RA, Xie DY and Sharma SB: Proanthocyanidins - a final frontier in flavonoid research? New Phytol 165: 9-28, 2005.

12. Pataki T, Bak I, Kovacs P, Bagchi D, Das DK and Toskai A: Grape seed proanthocyanidins improved cardiac recovery during reperfusion after ischemia in isolated rat hearts. Am J Clin Nutr 75: 894-899, 2002
13. Yamakoshi J, Kataoka S, Koga T and Ariga T: Proanthocyanidinrich extract from grape seeds attenuates the development of aortic atherosclerosis in cholesterol-fed rabbits. Atherosclerosis 142: 139-149, 1999.

14. Foo LY, Lu Y, Howell AB and Vorsa N: The structure of cranberry proanthocyanidins which inhibit adherence of uropathogenic Pfimbriated Escherichia coli in vitro. Phytochemistry 54: $173-181,2000$.

15. Subarnas A and Wagner H: Analgesic and anti-flammatory activity of the proanthocyanidin shellegueain A from polypodium feei METT. Phytomedicine 7: 401-405, 2000.

16. Deters A, Dauer A, Schnetz E, Fartasch M and Hensel A: High molecular weight compounds (polysaccharides and proanthocyanidins) from Hamamelis virginiana bark: influence on human skin keratinocyte proliferation and differentiation and influence on irritated skin. Phytochemistry 58: 949-958, 2001.

17. Hsu CP, Lin YH, Chou CC, Zhou SP, Hsu YC, Liu CL, Ku FM and Chung YC: Mechanisms of grape seed procyanidin-induced apoptosis in colorectal carcinoma cells. Anticancer Res 29: 283-289, 2009.

18. Akhtar S, Meeran SM, Katiyar N and Katiyar SK: Grape seed proanthocyanidins inhibit the growth of human non-small cell lung cancer xenografts by targeting insulin-like growth factor binding protein-3, tumor cell proliferation, and angiogenic factors. Clin Cancer Res 15: 821-831, 2009.

19. Zhang FJ, Yang JY, Mou YH, Sun BS, Ping YF, Wang JM, Bian XW and Wu CF: Inhibition of U-87 human glioblastoma cell proliferation and formyl peptide receptor function by oligomer procyanidins $(\mathrm{F} 2)$ isolated from grape seeds. Chem Biol Interact 179: 419-429, 2009.

20. Shang XJ, Yao G, Ge JP, Sun Y, Teng WH and Huang YF: Procyanidin induces apoptosis and necrosis of prostate cancer cell line PC-3 in a mitochondrion-dependent manner. J Androl 30: 122-126, 2009.

21. Pierini R, Kroon PA, Guyot S, Ivory K, Johnson IT and Belshaw NJ: Procyanidin effects on oesophageal adenocarcinoma cells strongly depend on flavan-3-ol degree of polymerization. Mol Nutr Food Res 52: 1399-1407, 2008.

22. King M, Chatelain K, Farris D, Jensen D, Pickup J, Swapp A, O'Malley S and Kingsley K: Oral squamous cell carcinoma proliferative phenotype is modulated by proanthocyanidins: a potential prevention and treatment alternative for oral cancer. BMC Complement Altern Med 7: 22, 2007.

23. Ramljak D, Romanczyk LJ, Metheny-Barlow LJ, Thompson N, Knezevic V, Galperin M, Ramesh A and Dickson RB: Pentameric procyanidin from Theobroma cacao selectively inhibits growth of human breast cancer cells. Mol Cancer Ther 4: 537-546, 2005.

24. Singh AP, Singh RK, Kim KK, Satyan KS, Nussbaum R, Torres M, Brard L and Vorsa N: Cranberry proanthocyanidins are cytotoxic to human cancer cells and sensitize platinum-resistant ovarian cancer cells to paraplatin. Phytother Res 23: 1066-1074, 2009.

25. Roy S, Khanna S, Alessio HM, Vider J, Bagchi D, Bagchi M and Sen CK: Anti-angiogenic property of edible berries. Free Radic Res 36: 1023-1031, 2002.

26. Brown MR, Blanchette JO and Kohn EC: Angiogenesis in ovarian cancer. Baillieres Best Pract Res Clin Obstet Gynaecol 14: 901-918, 2000.

27. Mantena SK, Baliga MS and Katiyar SK: Grape seed proanthocyanidins induce apoptosis and inhibit metastasis of highly metastatic breast carcinoma cells. Carcinogenesis 27: 1682-1691, 2006.

28. Strek M, Gorlach S, Podsedek A, Sosnowska D, Koziolkiewicz M, Hrabec Z and Hrabec E: Procyanidin oligomers from Japanese quince (Chaenomeles japonica) fruit inhibit activity of MMP-2 and MMP-9 metalloproteinases. J Agric Food Chem 16: 6447-6452, 2007.

29. Vayalil PK, Mittal A and Katiyar SK: Proanthocyanidins from grape seeds inhibit expression of matrix metalloproteinases in human prostate carcinoma cells, which is associated with the inhibition of activation of MAPK and NF kappa B. Carcinogenesis 25: 987-995, 2004.

30. Neuwirt H, Arias MC, Puhr M, Hobisch A and Culig Z: Oligomeric proanthocyanidin complexes (OPC) exert anti-proliferative and pro-apoptotic effects on prostate cancer cells. Prostate 68: 1647-1654, 2008.

31. Altomare DA, Wang HQ, Skele KL, De Rienzo A, Klein-Szanto AJ, Godwin AK and Testa JR: AKT and mTOR phosphorylation is frequently detected in ovarian cancer and can be targeted to disrupt ovarian tumor cell growth. Oncogene 23: 5853-5857, 2004. 
32. Vivanco I and Sawyers CL: The phosphatidylinositol 3-kinase AKT pathway in human cancer. Nat Rev Cancer 2: 489-501, 2002.

33. Yi T, Yi Z, Cho SG, Luo J, Pandey MK, Aggarwal BB and Liu M: Gambogic acid inhibits angiogenesis and prostate tumor growth by suppressing vascular endothelial growth factor receptor 2 signaling. Cancer Res 68: 1843-1850, 2008.

34. Liu M, Lin LQ, Song BB, Wang LF, Zhang CP, Zhao JL and Liu JR: Cranberry phytochemical extract inhibits SGC-7901 cell growth and human tumor xenografts in Balb/c nu/nu mice. J Agric Food Chem 57: 762-768, 2009.

35. Ferguson PJ, Kurowska EM, Freeman DJ, Chambers AF and Koropatnick J: In vivo inhibition of growth of human tumor lines by flavonoid fractions from cranberry extract. Nutr Cancer 56 : 86-94, 2006

36. Prasain JK, Jones K, Moore R, Barnes S, Leahy M, Roderick R, Juliana MM and Grubbs CJ: Effect of cranberry juice concentrate on chemically-induced urinary bladder cancers. Oncol Rep 19: 1565-1570, 2008.

37. Sun J and Hai Liu R: Cranberry phytochemical extracts induce cell cycle arrest and apoptosis in human MCF-7 breast cancer cells. Cancer Lett 241: 124-134, 2006.

38. Xue Y, Chen F, Zhang D, Lim S and Cao Y: Tumor-derived VEGF modulates hematopoiesis. J Angiogenes Res 1: 9, 2009.

39. Petit PX, Lecoeur H, Zorn E, Dauguet C, Mignotte B and Gougeon M: Alterations in mitochondrial structure and function are early events of dexamethasone-induced thymocyte apoptosis. J Cell Biol 130: 157-167, 1995.

40. Meeran SM and Katiyar SK: Proanthocyanidins inhibit mitogenic and survival-signalling in vitro and tumor growth in vivo. Front Biosci 13: 887-897, 2008

41. Engelbrecht AM, Mattheyse M, Ellis B, Loos B, Thomas M, Smith R, Peters S, Smith C and Myburgh K: Proanthocyanidin from grape seeds inactivates the PI3-kinase/PKB pathway and induces apoptosis in a colon cancer cell line. Cancer Lett 258 : 144-153, 2007.

42. Chaudhuri D, Orsulic S and Ashok BT: Antiproliferative activity of sulforaphane in Akt-overexpressing ovarian cancer cells. Mol Cancer Ther 6: 334-345, 2007.

43. Guo RX, Qiao YH, Zhou Y, Li LX, Shi HR and Chen KS Increased staining for phosphorylated AKT and nuclear factorkappaB p65 and their relationship with prognosis in epithelial ovarian cancer. Pathol Int 58: 749-756, 2008.

44. Kandel ES, Skeen J, Majewski N, Di Cristofano A, Pandolfi PP Feliciano CS, Gartel A and Hay N: Activation of Akt/protein kinase B overcomes a G(2)/m cell cycle checkpoint induced by DNA damage. Mol Cell Biol 22: 7831-7841, 2002.

45. Luo J, Manning BD and Cantley LC: Targeting the PI3K-Akt pathway in human cancer: rationale and promise. Cancer Cell 4: 257-262, 2003.

46. Nicosia SV, Bai W, Cheng JQ, Coppola D and Kruk PA: Oncogenic pathways implicated in ovarian epithelial cancer. Hematol Oncol Clin North Am 17: 927-943, 2003.

47. Pawlik TM and Keyomarsi K: Role of cell cycle in mediating sensitivity to radiotherapy. Int J Radiat Oncol Biol Phys 59: 928-942, 2004

48. Hartwell LH and Kastan MB: Cell-cycle control and cancer. Science 266: 1821-1828, 1994.
49. Aggarwal P, Lessie MD, Lin DI, Pontano L, Gladden AB, Nuskey B, Goradia A, Wasik MA, Klein-Szanto AJ, Rustgi AK, Bassing CH and Diehl JA: Nuclear accumulation of cyclin D1 during S phase inhibits Cul4-dependent Cdt1 proteolysis and triggers p53-dependent DNA rereplication. Genes Dev 21: 2908-2922, 2007.

50. Pines J: Four-dimensional control of the cell-cycle. Nature Cell Biol 1: 73-79, 1999.

51. Stillman B: Cell-cycle control of DNA replication. Science 274: 1659-1664, 1996.

52. Shapiro GI and Harper JW: Anticancer drug targets: cell-cycle and checkpoint control. J Clin Invest 104: 1645-1653, 1999.

53. Mazumder S, DuPree EL and Almasan A: A dual role of cyclin E in cell proliferation and apoptosis may provide a target for cancer therapy. Curr Cancer Drug Targets 4: 65-75, 2004

54. Chung WG, Miranda CL, Stevens JF and Maier CS: Hop proanthocyanidins induce apoptosis, protein carbonylation, and cytoskeleton disorganization in human colorectal adenocarcinoma cells via reactive oxygen species. Food Chem Toxicol 47: 827-386, 2009

55. Galanis A, Pappa A, Giannakakis A, Lanitis E, Dangaj D and Sandaltzopoulos R: Reactive oxygen species and HIF-1 signalling in cancer. Cancer Lett 266: 12-20, 2008.

56. Hileman EO, Liu J, Albitar M, Keating MJ and Huang P: Intrinsic oxidative stress in cancer cells: a biochemical basis for therapeutic selectivity. Cancer Chemother Pharmacol 53: 209-219, 2004.

57. Trachootham D, Alexandre J and Huang P: Targeting cancer cells by ROS-mediated mechanisms: a radical therapeutic approach? Nat Rev Drug Discov 8: 579-591, 2009.

58. Mansat-de Mas V, Bezombes C, Quillet-Mary A, Bettaïeb A, D'orgeix AD, Laurent $G$ and Jaffrézou JP: Implication of radical oxygen species in ceramide generation, c-Jun N-terminal kinase activation and apoptosis induced by daunorubicin. Mol Pharmacol 56: 867-874, 1999.

59. Osone S, Hosoi H, Kuwahara Y, Matsumoto Y, Lehara T and Sugimoto T: Fenretinide induces sustained-activation of JNK p38 MAPK and apoptosis in a reactive oxygen species-dependent manner in neuroblastoma cells. Int J Cancer 112: 219-224, 2004.

60. Tsai-Turton M, Luong BT, Tan Y and Luderer U: Cyclophosphamide-induced apoptosis in COV434 human granulosa cells involves oxidative stress and glutathione depletion. Toxicol Sci 98: 216-230, 2007.

61. Wen W, Lu J, Zhang K and Chen S: Grape seed extract inhibits angiogenesis via suppression of the vascular endothelial growth factor receptor signaling pathway. Cancer Prev Res 1: 554-561, 2008.

62. Bamberger ES and Perrett CW: Angiogenesis in epithelian ovarian cancer. Mol Pathol 55: 348-359, 2002.

63. Sánchez-Muñoz A, Pérez-Ruiz E, Mendiola Fernández C, Alba Conejo E and González-Martín A: Current status of anti-angiogenic agents in the treatment of ovarian carcinoma. Clin Transl Oncol 11: 589-595, 2009.

64. Tran J, Master Z, Yu JL, Rak J, Dumont DJ and Kerbel RS: A role for survivin in chemoresistance of endothelial cells mediated by VEGF. Proc Natl Acad Sci USA 99: 4349-4354, 2002. 